\title{
Intestinal Duplications - Experience in 6 Cases
}

\section{Stanko Ćavar Marko Bogović Tomislav Luetić Anko Antabak Stipe Batinica}

Department of Pediatric Surgery, Clinical Hospital Center Rebro, Zagreb, Croatia

\section{Key Words}

Intestinal duplications · Gastrointestinal congenital anomalies $\cdot$ Literature review, intestinal duplications

\begin{abstract}
Intestinal duplications are rare congenital anomalies, and most of them are detected in the first 2 years of life or antenatally. The clinical presentation depends on location, size, and the presence of ectopic gastric mucosa. Ultrasound scans during pregnancy result in a higher rate of antenatally detected duplications which allows early treatment and avoidance of possible complications. Resection of the duplication without adjacent bowel should be the treatment of choice. En bloc resection or partial excision with mucosectomy is advised in some cases. We present our experience with 6 patients treated in our institution from February 2002 to October 2005.

Copyright $\odot 2006$ S. Karger AG, Basel
\end{abstract}

\section{Introduction}

Intestinal duplications are reported to be present in approximately 1 in 4,500 neonatal autopsies or in 1 in 18,000 livebirths [1]. Regardless of their location, they have three common features: hollow structures, lined with gastrointestinal tract epithelium, and have a wall of smooth muscle often shared with the contiguous intestinal tract. The duplications are classified according to their location (ileum $30 \%$, ileocecal valve $30 \%$, duodenum $10 \%$, stomach $8 \%$, jejunum $8 \%$, colon $7 \%$, rectum $5 \%)$, shape - cystic $(>80 \%)$ or tubular -, and presence of ectopic tissue within the duplication (gastric mucosa present in up to $50 \%$ of the cases) [2]. Additional classification for small-intestine duplications considering vascular supplies to the duplication and the adjacent bowel is also reported [3].

Although considered to be benign, such duplications can have even lethal consequences if not properly treated [4]. The symptoms are unspecific and vary from minor digestive problems to intestinal obstruction, gastrointestinal bleeding, or perforation [5]. The number of antenatally detected duplications is increasing which allows early treatment with fewer complications. If the diagnosis is unclear, some additional imaging procedures can be used: barium swallow, radionuclide scan, or CT scan.

Surgical treatment depends mostly on the location of the duplications in relation to adjacent bowel or other structures like bile ducts and blood vessels. Postoperative complications are rare and unspecific: bleeding, infection, and bowel obstruction. Surgically treated intestinal duplications have a good prognosis.

\section{KARGER \\ Fax +41613061234 E-Mail karger@karger.ch} www.karger.com
Marko Bogović, MD

Department of Pediatric Surgery

Clinical Hospital Center Rebro

Kispaticeva 12

10000 Zagreb (Croatia) 


\section{Patients and Methods}

Between 2002 and 2005, at the Department of Pediatric Surgery of the Clinical Hospital Center Rebro, 6 children were surgically treated for intestinal duplications. There were 3 boys and 3 girls with an age range from 27 days to 2 years and 10 months (mean age 13 months; table 1 ).

Three of our patients had symptoms of intestinal obstruction, 1 child presented with signs of intestinal perforation (pneumo-

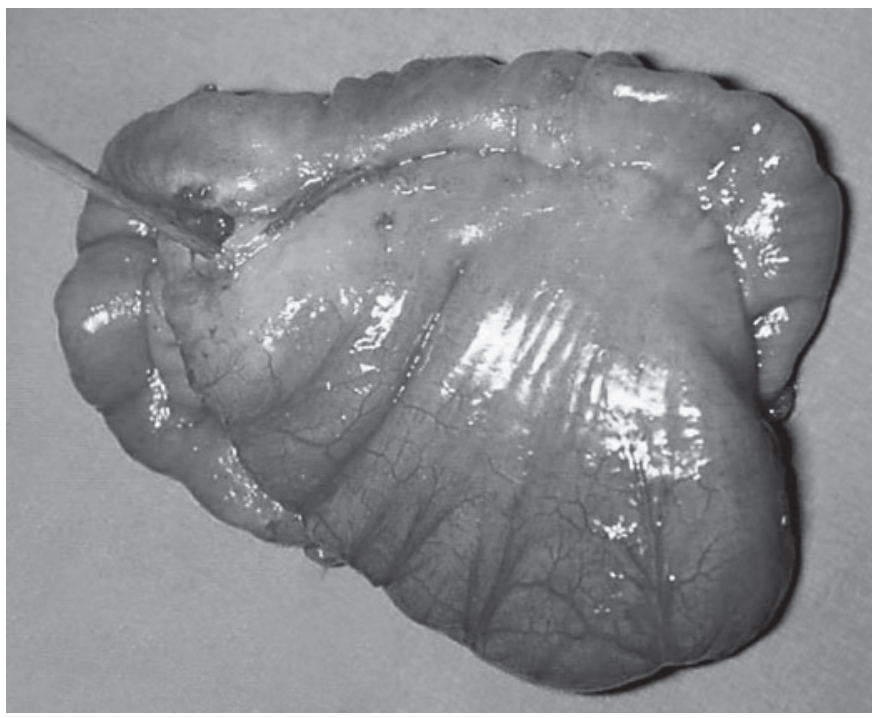

peritoneum; fig. 1), 1 had chronic anemia with rectorrhagia and melena, and in 1 case the diagnosis was made prenatally.

We have used the following diagnostic procedures: ultrasound in all cases and barium swallow when needed, CT scan, and radionuclide $\left[{ }^{99 \mathrm{~m}} \mathrm{Tc}\right]$ pertechnetate macroaggregated albumin scan for detection of gastric mucosa.

The intestinal duplication was highly suspected in 4 cases (in 1 the diagnosis was made prenatally), in 1 case (a 5-month-old girl) the differential diagnosis was an ovarian cyst, and in 1 case Meckel's diverticulum was suspected (chronic anemia, rectal bleeding, positive radionuclide scan). We had two duodenal, one ileal, two cecal, and one colonic duplication.

The surgical procedure was laparotomy, and we have performed complete excision of the duplication without opening the adjacent bowel in 1 case, in 3 cases we underwent en bloc excision with the adjacent bowel, and in 2 cases we performed partial excison with mucosectomy. There were four cystic and two tubular duplications. Communication with the adjacent bowel was confirmed in 2 cases. We had two postoperative complications: one dehiscence of the blind end of the anastomosis and one wound infection.

Mucosa of intestinal type together with gastric mucosa was found in 3 patients, another had pancreatic cells as well as gastric and intestinal mucosae, and the intestine of 1 patient was lined with only intestinal-type mucosa and in 1 patient only with gastric mucosa. During the follow-up period (ranging from 2 months to 4 years) all of our patients did well.

Fig. 1. Cystic duplication resected together with the adjacent part of the ileum. A wooden stick is inserted through the perforated opening of the duplication.

Table 1. Intestinal duplications: clinical presentation, location, treatment, and type of mucosa found

\begin{tabular}{|c|c|c|c|c|c|c|c|}
\hline Age/sex & $\begin{array}{l}\text { Clinical } \\
\text { presentation }\end{array}$ & $\begin{array}{l}\text { Working } \\
\text { diagnosis }\end{array}$ & $\begin{array}{l}\text { Intraoperative } \\
\text { findings } \\
\text { and locations }\end{array}$ & Surgical procedures & Histological findings & Complications & $\begin{array}{l}\text { Outcome and } \\
\text { follow-up } \\
\text { period }\end{array}$ \\
\hline 8 months $/ \mathrm{m}$ & $\begin{array}{l}\text { abdominal pain, } \\
\text { fever }\end{array}$ & duplication & $\begin{array}{l}\text { perforation of ileal } \\
\text { duplication }\end{array}$ & $\begin{array}{l}\text { resection en bloc with } \\
\text { adjacent bowel, end- } \\
\text { to-end anastomosis }\end{array}$ & $\begin{array}{l}\text { mucosa of intestinal } \\
\text { type together with } \\
\text { gastric mucosa }\end{array}$ & none & $\begin{array}{l}\text { good, } \\
3 \text { years }\end{array}$ \\
\hline $\begin{array}{l}2 \text { years and } \\
10 \text { months/f }\end{array}$ & obstruction & duplication & $\begin{array}{l}\text { pyloroduodenal } \\
\text { duplication }\end{array}$ & marsupialization & $\begin{array}{l}\text { mucosa of intestinal } \\
\text { type together with } \\
\text { gastric mucosa }\end{array}$ & none & $\begin{array}{l}\text { good, } \\
13 \text { months }\end{array}$ \\
\hline 15 months/m & $\begin{array}{l}\text { gastrointestinal } \\
\text { bleeding }\end{array}$ & $\begin{array}{l}\text { Meckel's } \\
\text { diverticulum }\end{array}$ & cecal duplication & $\begin{array}{l}\text { excision of the } \\
\text { duplication }\end{array}$ & gastric mucosa & none & $\begin{array}{l}\text { good, } \\
17 \text { months }\end{array}$ \\
\hline 17 months/f & obstruction & $\begin{array}{l}\text { duplication or } \\
\text { hypertrophic } \\
\text { pyloric stenosis }\end{array}$ & duodenal duplication & marsupialization & $\begin{array}{l}\text { mucosa of intestinal } \\
\text { type together with } \\
\text { gastric mucosa and } \\
\text { pancreatic cells }\end{array}$ & none & $\begin{array}{l}\text { good, } \\
9 \text { months }\end{array}$ \\
\hline 27 days/m & obstruction & duplication & ileocecal duplication & $\begin{array}{l}\text { resection en bloc with } \\
\text { adjacent bowel, side- } \\
\text { to-side anastomosis }\end{array}$ & $\begin{array}{l}\text { mucosa of intestinal } \\
\text { type }\end{array}$ & $\begin{array}{l}\text { dehiscence of the } \\
\text { blind end of the } \\
\text { anastomosis }\end{array}$ & $\begin{array}{l}\text { good, } \\
15 \text { months }\end{array}$ \\
\hline 5 months/f & none & ovarian cyst & cecal duplication & $\begin{array}{l}\text { resection en bloc with } \\
\text { adjacent bowel, end-to- } \\
\text { side anastomosis }\end{array}$ & $\begin{array}{l}\text { mucosa of intestinal } \\
\text { type together with } \\
\text { gastric mucosa }\end{array}$ & wound infection & $\begin{array}{l}\text { good, } \\
2 \text { months }\end{array}$ \\
\hline
\end{tabular}




\section{Discussion}

Gastrointestinal duplications are rare congenital anomalies which are in $85 \%$ of the patients detected prenatally or in the first 2 years of life, but can remain undetected until older age [6]. Possible complications like bowel perforation, bleeding, obstruction, and malignant alterations are the reason why all duplications should be surgically treated at the time of diagnosis.

The clinical picture varies according to location, size, and other factors such as the presence of ectopic mucosa within the duplication, communication with adjacent bowel, or inflammation. The most common clinical manifestations are abdominal pain and intestinal obstruction. Rarely, such duplications present with signs of acute abdomen or acute bleeding. Pyloric and duodenal duplications can mimic hypertrophic pyloric stenosis (considered in 2 of our patients with episodes of vomiting and signs of dudodenal obstruction) or a choledochal cyst $[7,8]$. An ovarian cyst should be considered in female patients, and adolescent patients can sometimes have a presumptive diagnosis of Crohn's disease.

Ultrasound is the imaging modality of choice for the evaluation of an abdominal mass in the neonate. Aproximately $30 \%$ of the intestinal duplications are diagnosed prenatally [9]. Some ultrasonographic features like hyperechoic mucosa and hypoechoic muscle layer (doublewall sign) and peristalsis when visible are specific for duplications. Additional imaging procedures are sometimes required: barium enema, CT scan, radionuclide scan (HIDA scan for choledochal cyst and pertechnetate scan for Meckel's diverticulum). However, gastric, duodenal, and rectal duplications can lead to a diagnostic dilemma.

Intestinal duplications often require urgent surgical intervention. Secretion of ectopic gastric mucosa causes ulceration of the intestinal mucosa which can lead to massive bleedings or bowel perforation [10]. Most of the authors [11] believe that once the diagnosis is made, an elective surgical procedure should be performed to avoid complications and to perform the procedure in an optimal state of the patient, but few think that only symptomatic duplications should be surgically treated. Our patient who presented with bowel perforation had duplication detected 4 months earlier, but the parents refused the indicated elective surgical procedure.

The recommended surgical procedure is excision of the duplication, and recent studies on vascular supplies for small-intestine duplications show that it is possible to resect them without compromising the adjacent bowel vascularization. However, it is sometimes not possible (especially in cases with locations like the duodenum) because of shared wall and vascularization with adjacent bowel. Resection 'en block' of the duplication with adjacent bowel is then advised. Other procedures like marsupialization with mucosectomy, internal drainage, and Wrenn's operation are also advised when necessary. We had two duodenal duplications (one at the first and the other at the second duodenal segment) without communication with the adjacent bowel. Duodenal duplications rarely communicate with adjacent parts of the intestinal tract, and because of their close contact with bile and pancreatic ducts (can cause icterus or pancreatitis) it is often impossible to perform complete excision [12]. To avoid possible lesions of pancreas or choledochal duct, we have done mucosectomy with marsupialization. Both of these patients were postoperatively well and without complications which makes this procedure recommendable for duodenal duplications to avoid lesions of adjacent structures. In 3 of our patients, we had to perform 'en bloc' resection, and in 1 patient we completely excised the duplication without compromising the adjacent bowel. Laparoscopically assisted resection with or without small laparotomy has been reported and is recommnended for uncomplicated cases.

Intestinal-type mucosa is found in most of the cases, and in $16-39 \%$ of the patients ectopic gastric or pancreatic cells are found. The mucosa should always be removed because of the malignant potential of ectopic tissue.

\section{Conclusions}

Intestinal duplications are rare congenital anomalies which vary in clinical presentation and complication rates such as bowel obstruction, gastrointestinal bleeding, bowel perforation, or malignant alterations. The increasing number of prenatally diagnosed duplications allows early planning and treatment, with the patients being in optimal conditions. Early diagnosis and treatment reduces the risk of dangerous complications like bowel perforation, bleeding, obstruction, and malignant alterations. Resection of a duplication alone is the treatment of choice, and in uncomplicated cases laparoscopic resection is advised. Gastric mucosa is often found in duplications. The prognosis of surgically treated patients is excellent. 


\section{References}

1 Potter EL: Pathology of the Fetus and Newborn. Chicago, Year Book Medical Publishers, 1961.

-2 Stern LE, Warner BW: Gastrointestinal duplications. Semin Pediatr Surg 2000;9:135140.

3 Li L, Zhang JZ, Wang YX: Vascular classification for small intestinal duplications: experience with 80 cases. J Pediatr Surg 1998; 33:1243-1245.

4 Orr MM, Edwards AJ: Neoplastic change in duplications of the alimentary tract. Br J Surg 1975;62:269-274.
5 Ildstad ST, Tollerud DJ, Weiss RG, Ryan DP, McGowan MA, Martin LW: Duplication of the alimentary tract: clinical characteristics, preferred treatment, and associated malformations. Ann Surg 1988;208:184-189.

6 Anderson MC, Silberman WW, Shields TW: Duplications of the alimentary tract in the adult. Arch Surg 1962;85:94-108.

7 Merrot T, Anastasescu R, Pankevych T, Tercier S, Garcia S, Alessandrini P, Guys JM: Duodenal duplications: clinical characteristics, embryological hypotheses, histological findings, treatment. Eur J Pediatr Surg 2006; 16:18-23.

$\checkmark 8$ Lavine JE, Harrison M, Heyman MB: Gastrointestinal duplications causing relapsing pancreatitis in children. Gastroenterology 1989;97:1556-1558.
$\$ 9$ Foley PT, Sithasanan N, McEwing R, Lipsett J, Ford WD, Furness M: Enteric duplications presenting as antenatally detected abdominal cysts: is delayed resection appropriate? J Pediatr Surg 2003;38:1810-1813.

10 Wardell S, Vidican DE: Ileal duplication cyst causing massive bleeding in a child. J Clin Gastroenterol 1990;12:681-684.

11 Schalamon J, Schleef J, Höllwarth M: Experience with gastrointestinal duplications in childhood. Langenbecks Arch Surg 2000; 385:402-405.

12 Stringer MD, Spitz L, Abel R, Kiely E, Drake DP, Agrawal M, Stark Y, Brereton RJ: Management of alimentary tract duplications in children. Br J Surg 1995;82:74-78. 